\title{
Predicting Soil Erosion and Sediment Yield in Oued El Abid Watershed, Morocco
}

\author{
By El Mouatassime Sabri* \\ Ahmed Boukdir \\ Rachid El Meslouhi \\ Mustapha Mabrouki ${ }^{+}$ \\ Abdallah El Mahboul \\ Vivien Romaric Ekouele Mbaki* \\ Abdelhamid Zitouni* \\ Wissal Baite \\ Zhour Echakraoui
}

\begin{abstract}
This study was conducted in the Oued El Abid watershed upstream of the Bin El Ouidane dam, in Tadla-Azilal province to quantify the dam siltation rates. To assess the annual soil erosion and the sediment yield the universal soil loss equation (USLE) was used. A geographic information system (GIS) was used to generate and integrate maps of the USLE factors. A spatial distribution of soil erosion in the Oued El Abid watershed was obtained. The soil erosion was determined for each rural commune in order to identify the soil erosion hotspot and estimate the amount of soil that has been transported downstream (Bin El Ouidane Dam). Soil erosion ranged from very limited values for flat and well covered areas to over $2100 \mathrm{t} / \mathrm{ha}$ /y in mountainous areas with sparse vegetation. The total annual soil loss within the watershed is estimated at 19.6 million tons per year. An equation of the sediment delivery ratio (SDR) based on river gradient was calculated. It was found that the value of SDR at the outlet of the watershed Oued El Abid was 0.65 with a sediment yield of 12.74 million tons per year which affect the durability of the dam.
\end{abstract}

Keywords: Erosion, GIS, SDR, Soil, USLE.

\section{Introduction}

\footnotetext{
* PhD Student, Sultan Moulay Slimane University, Morroco.

${ }^{\dagger}$ Professor, Sultan Moulay Slimane University, Morroco.

* Hydrological Basin Agency, Morocco.

${ }^{+}$Professor, Sultan Moulay Slimane University, Morroco.

- Secretary, Minister of Energy, Mining, Water, Morocco.

- PhD Student, Sultan Moulay Slimane University, Morroco.

* PhD Student, Sultan Moulay Slimane University, Morroco.

^ PhD Student, Sultan Moulay Slimane University, Morroco.

PhD Student, Sultan Moulay Slimane University, Morroco.
} 
Soil erosion is a complex dynamic process by which productive soil particles are detached, transported and accumulated in a distant place.This results in the exposure of subsurface soil and sedimentation in reservoirs (Alexakis et al., 2013). In Morocco, the dam siltation retained annually reduces the storage capacity of 75 million $\mathrm{m}^{3}$, which represents $0.005 \%$ of the annual water mobilization with a total shortfall of 1 billion dollars per year. Out of the total area of $710850 \mathrm{Km}^{2}$ of Morocco, it is estimated that about $150000 \mathrm{~km}^{2}$ is affected by serious water and wind erosion (Namr and Mrabet, 2004).

The entire downstream area of the High Atlas mountain chain is affected by a serious problem of soil erosion. All rivers flowing through this region transport a heavy load of sediment which is then trapped in several reservoirs. In this respect, this study aims at highlighting the relationships between the biophysical and hydrological conditions that control the erosion processes in Oued El Abid watershed upstream of the Bin El Ouidane dam which knew a shortage in its capacity of 274.5 million $\mathrm{m}^{3}$ between 1954 and 2008 with an average shortfall of 5 million $\mathrm{m}^{3}$ per year (ABHOER, 2015).

However, it is complicated to model soil erosion of the entanglement of factors that push the erosion process (Zhu et al., 2013). Many soil erosion models have been developed, ranging from simple empirical equations, such as the Universal Soil Loss Equation (USLE) (Wischmeier and Smith, 1978) and its revised version, RUSLE (Renard et al., 1997), to more sophisticated models, such as the Water Erosion Prediction Project (WEPP) (Flanagan et al., 2007) and EUROSEM (Morgan et al., 1998). The latter may be preferable than the empirical models, anyhow those models regularly need plenty of data and are more efficient to use in many circumstances, particularly to model soil erosion in medium- and large-scale watersheds (Wang et al., 2009). On the contrary, the USLE has been extensively applied all over the world at many scales mainly due to the simplicity of the model formulation and the possibility to estimate the input parameters with limited input data (Wang et al., 2009).

The USLE provides an estimation of the sediment mobilized by surface runoff, but is not able to model whether the sediment will be exported out of the catchment or re-deposited as colluvium or alluvium within the catchment (Hui et al., 2010). In fact, the sediment delivery ratio (SDR) was introduced to estimate the sediment yield in Bin El Ouidane reservoir based on the slop of drainage line extracted from the Data Elevation Model using Arc Hydro tools which is a geospatial and temporal data model for water resources designed to operate within ArcGIS (Zhang et al. 2010).

\section{General Framework of the Study Area}

The watershed of Oued El Abid with an area of $7686 \mathrm{~km}^{2}$ is the upper part of the great Oum Er Rabia drainage basin of $50000 \mathrm{~km}^{2}$ (see Figure 1A). The Oued El Abid watershed is located upstream of the Bin El Ouidane dam in the region of Tadla Azilal between the High Atlas and the plain of Tadla. The main water course is the Oued El Abid, one of the most important water resources of Morocco which is used for irrigation and hydropower. The watershed stretches 
over three different provinces and is divided into 27 administrative rural communities (see Figure 1B).

Figure 1. Study Area Localization

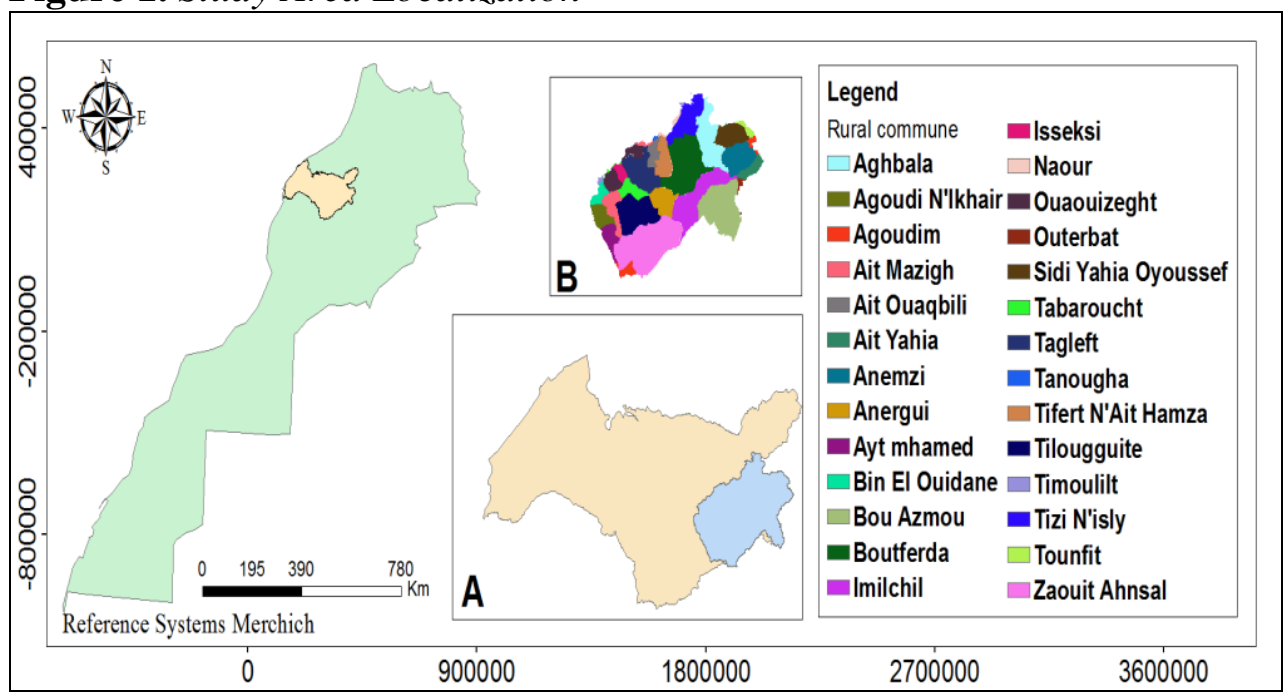

\section{Methodological Approach}

The general methodology (see Figure 2) involves the use of the USLE in a GIS environment. The individual raster layers were calculated for each USLE factor and processed in a GIS. The product of those factors has given the annual loss of soil in the entire watershed.

Figure 2. Schematic of the Approach Used

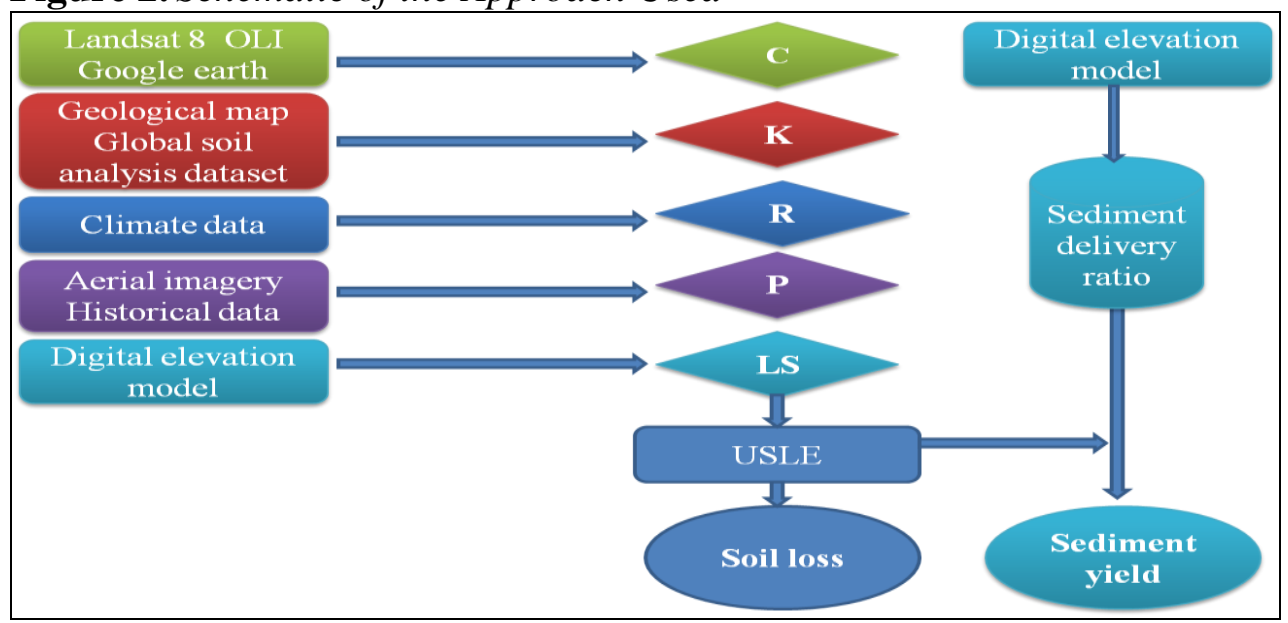

The sediment yield was calculated using the sediment delivery ratio (SDR) based on river gradient extracted from ASTER satellite imagery using arc hydro tools (Burns and Nolin, 2014).

Application of the Universal Soil Loss Equation (USLE) 
The proposed method is based on the universal soil loss equation (Wischmeier and Smith, 1978). This equation provides the average annual erosion for a long period of time based on the slope of a field, data of rainfall, cropping system and management practice. Five key factors are used to calculate soil loss at a given location. Each factor is a numerical estimate of a particular component which affects the severity of soil erosion at that location.

$\mathrm{A}=\mathrm{R} * \mathrm{~K} * \mathrm{LS} * \mathrm{C} * \mathrm{P}$

A: expresses the potential average annual soil loss in (Tonne / ha / y).

$\mathrm{R}$ : corresponds to the Rainfall erosivity factor.

$\mathrm{K}$ : is the soil erodibility factor.

LS: is the length factor and slope gradient.

C: corresponds to the land use factor.

$\mathrm{P}:$ is the conservation practice factor.

\section{Topographic Factor LS}

The LS factor was calculated using the following equation (see Equation 1) (Stone and Hilborn, 2012):

$$
L S=\left[0.065+0.0456(\text { Slope })+0.0065(\text { Slope })^{2}\right]\left(\frac{\text { Slope length }}{22.1}\right)^{0.5}
$$

Where: Slope $=$ slope steepness in $\%$.

Slope length $=$ (flow accumulation $*$ cell resolution) in $\mathrm{m}$ (Van Remortel et al., 2004 ; Suhua et al., 2013).

The slope was extracted from SRTM with $30 \mathrm{~m}$ resolution (see Figure 3) using arc hydro extension.

Figure 3. Data Elevation Model 


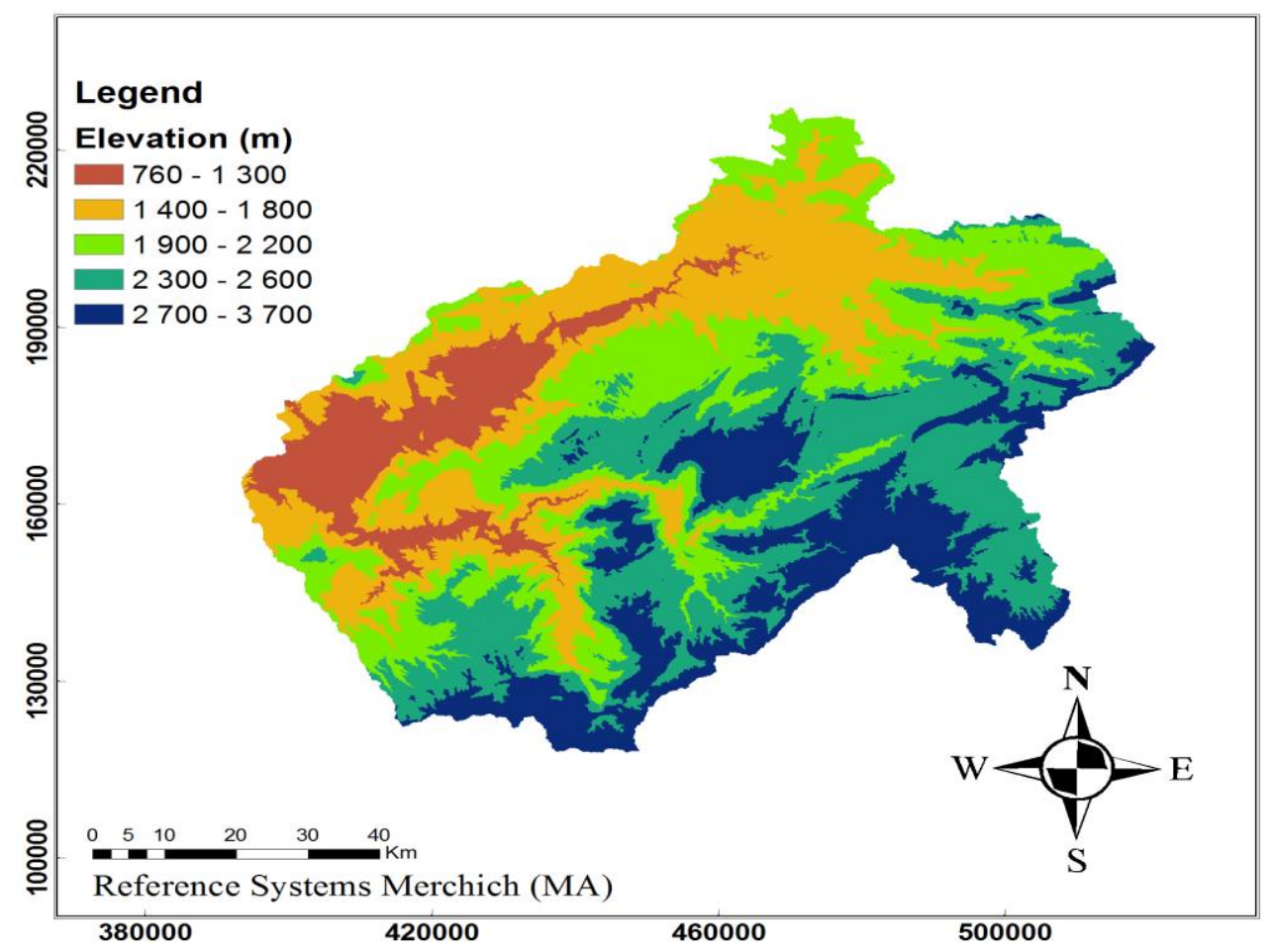

$\underline{\text { Rainfall Erosivity Factor R }}$

In terms of climate, the watershed has a rainy winter and a dry summer. (Hui et al., 2010) The precipitation regime is irregular and the rainy period concentrated between the months of October and May.

To estimate this factor we have used the equation Eq.2 which was used by FAO in Morocco to develop an iso-erodent (Hui et al., 2010) .

The equation expressed as follow (see Equation 2):

$$
R=0.264 \times F^{1.5}
$$

F is the Fournier index modified expressed as follow (see Equation 3):

$$
F=\sum_{i=1}^{12} \frac{r i}{P}
$$

where $r_{i}$ is the precipitation in the month $i$ and $P$ is the annual precipitation.

Table 1. Station Localization and Measurement Period

\begin{tabular}{|l|c|c|c|c|}
\hline Station name & $\begin{array}{c}\text { Station } \\
\text { Number }\end{array}$ & $\mathbf{X}(\mathbf{m})$ & $\mathbf{Y}(\mathbf{m})$ & $\begin{array}{c}\text { Measurement } \\
\text { period }\end{array}$ \\
\hline Z. Ahansal & 8946 & 433282 & 137886 & $1984-2014$ \\
\hline Toufint & 5536 & 432300 & 139600 & $1969-2014$ \\
\hline Tillouguit & 8298 & 422670 & 158500 & $1979-2014$ \\
\hline Taghzirt & 7488 & 423900 & 205600 & $1967-2014$ \\
\hline Sgatt & 6624 & 377800 & 136100 & $1953-2014$ \\
\hline O. Driss & 6104 & 338950 & 192600 & $1969-2014$ \\
\hline
\end{tabular}




\begin{tabular}{|l|c|c|c|c|}
\hline Tizi N Isly & 8500 & 467680 & 201500 & $1975-2014$ \\
\hline M. Eddahk & 6472 & 394980 & 204800 & $1968-2014$ \\
\hline C.N.Amllah & 2558 & 467800 & 243300 & $1975-2014$ \\
\hline ASSAKA & 1304 & 348450 & 138100 & $1964-2014$ \\
\hline A.Segmin & 844 & 361400 & 128000 & $1971-2014$ \\
\hline A. ouchen & 812 & 534553 & 213845 & $1975-2014$ \\
\hline Ademaghn & 53 & 372900 & 125400 & $1983-2014$ \\
\hline
\end{tabular}

The Gauging stations selected have an acceptable spatial coverage (see Figure 4) and long periods of observation (see Table 1) and allow a prominent climate analysis of Oued El Abid watershed. The annual rainfall ranges from $200 \mathrm{~mm}$ in the North to $500 \mathrm{~mm}$ in the East. 
Figure 4. Spatial Coverage of Gauging Stations

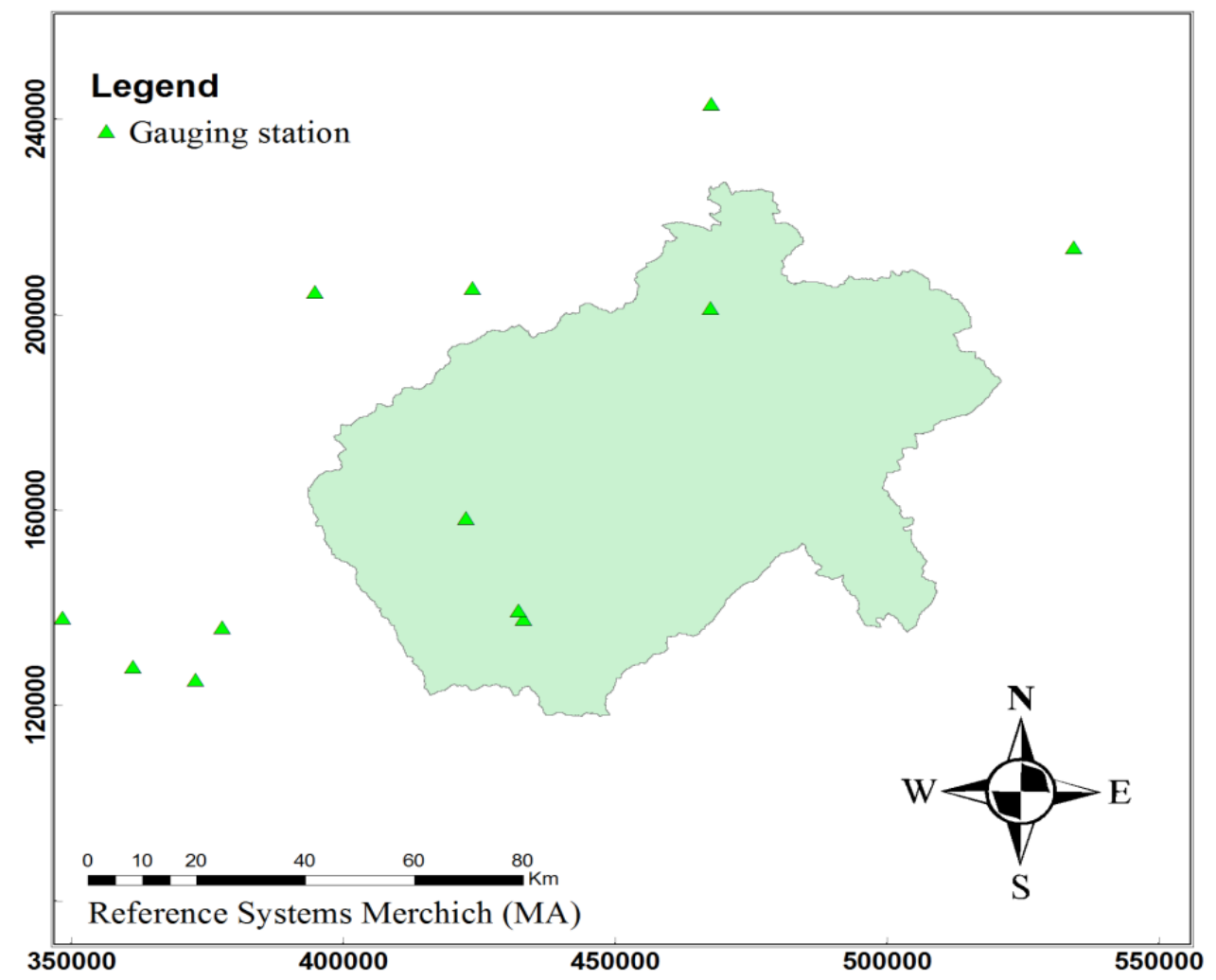

\section{$\underline{\text { Soil Erodibility Factor K }}$}

Erodibility $(\mathrm{K})$ is a function of the organic material and the texture of the soil, the permeability and the profile structure. $\mathrm{K}$ is defined as a measure of the susceptibility of soil particles to detachment and transport by rainfall and runoff (Panagos et al., 2014). It varies from 0.70 for the most fragile soils to 0.01 on the most stable soils (El Garouani et al., 2008).

Our results are obtained by using soil analysis of 54 soil samples (see table 2) and aggregate the data of the soil analysis provided by FAO in their harmonized database of the World Soil (Dewitte et al., 2013) and Sheet information of OMAFRA based on USLE (Stone and Hilborn, 2012).

\section{$\underline{\text { Vegetation Cover Factor C }}$}

The land cover map is obtained from the recent (2013/2014) Landsat 8 OLI satellite image with $30 \mathrm{~m}$ resolution using the supervised classification. The use of the Google earth image has brought more details especially for forests classes. The kappa coefficient calculated from the confusion matrix is used to determine the accuracy of the supervised classification. 
Table 2. Soil Analysis Data

\begin{tabular}{|c|c|c|c|c|c|c|c|c|}
\hline $\mathbf{N}$ & $\mathbf{X}(\mathbf{m})$ & $\mathbf{Y}(\mathbf{m})$ & $\mathbf{Z}(\mathbf{m})$ & $\begin{array}{l}\text { Sand } \\
(\%)\end{array}$ & $\begin{array}{l}\text { silt } \\
(\%)\end{array}$ & $\begin{array}{l}\text { Organic } \\
\text { Matter (\%) }\end{array}$ & $\begin{array}{l}\text { Clay } \\
(\%)\end{array}$ & $\begin{array}{c}\text { Density } \\
\left(t / m^{3}\right)\end{array}$ \\
\hline P1 & 345637 & 184470 & 263 & 49 & 17 & 8 & 34 & 2.40 \\
\hline P2 & 344284 & 189718 & 266 & 45 & 18 & 10 & 37 & 2.50 \\
\hline P3 & 346298 & 173082 & 285 & 48 & 15 & 10 & 37 & 2.55 \\
\hline P4 & 368941 & 159905 & 560 & 47 & 21 & 13 & 32 & 2.30 \\
\hline P5 & 390459 & 170007 & 670 & 44 & 23 & 14 & 33 & 2.45 \\
\hline P6 & 399180 & 167559 & 845 & 45 & 21 & 12 & 34 & 2.25 \\
\hline P7 & 414547 & 171025 & 842 & 50 & 22 & 10 & 28 & 2.48 \\
\hline P8 & 411017 & 171767 & 915 & 53 & 20 & 9 & 27 & 2.24 \\
\hline P9 & 413438 & 177963 & 1433 & 49 & 23 & 9 & 28 & 2.40 \\
\hline P10 & 426061 & 179763 & 909 & 44 & 24 & 11 & 32 & 2.70 \\
\hline P11 & 419074 & 182648 & 1416 & 49 & 21 & 8 & 30 & 2.60 \\
\hline P12 & 428600 & 181453 & 1098 & 49 & 21 & 10 & 30 & 2.50 \\
\hline P13 & 440598 & 189712 & 1114 & 43 & 25 & 12 & 31 & 2.60 \\
\hline P14 & 448196 & 191857 & 1404 & 43 & 25 & 13 & 32 & 2.45 \\
\hline P15 & 460365 & 194792 & 1555 & 44 & 26 & 9 & 30 & 2.50 \\
\hline P26 & 473463 & 193341 & 1530 & 46 & 23 & 12 & 30 & 2.40 \\
\hline P27 & 477042 & 203032 & 1562 & 45 & 24 & 8 & 31 & 2.45 \\
\hline $\mathrm{P} 28$ & 474299 & 200025 & 1384 & 45 & 23 & 7 & 32 & 2.66 \\
\hline P29 & 473671 & 207147 & 1535 & 45 & 22 & 11 & 33 & 2.40 \\
\hline P30 & 463220 & 207420 & 1454 & 45 & 23 & 10 & 32 & 2.45 \\
\hline P31 & 410229 & 164435 & 1211 & 47 & 22 & 11 & 32 & 2.22 \\
\hline P32 & 423739 & 159237 & 1137 & 52 & 20 & 10 & 28 & 2.40 \\
\hline P33 & 428461 & 155976 & 1151 & 45 & 25 & 18 & 30 & 2.60 \\
\hline P34 & 434055 & 147979 & 1367 & 44 & 24 & 14 & 32 & 2.24 \\
\hline P35 & 435443 & 153220 & 1734 & 43 & 24 & 13 & 33 & 2.50 \\
\hline P36 & 438287 & 164126 & 1294 & 49 & 19 & 12 & 33 & 2.45 \\
\hline P37 & 448972 & 163708 & 1486 & 46 & 22 & 11 & 32 & 2.24 \\
\hline P38 & 418806 & 185929 & 1707 & 45 & 23 & 8 & 32 & 2.24 \\
\hline P39 & 434579 & 187102 & 1409 & 44 & 26 & 12 & 30 & 2.50 \\
\hline $\mathrm{P} 40$ & 440235 & 196160 & 1600 & 46 & 26 & 10 & 28 & 2.20 \\
\hline P41 & 444117 & 208698 & 1052 & 47 & 24 & 11 & 29 & 2.45 \\
\hline P42 & 452653 & 207356 & 1322 & 48 & 23 & 11 & 29 & 2.40 \\
\hline P43 & 467816 & 199214 & 1420 & 45 & 24 & 12 & 31 & 2.40 \\
\hline P44 & 476825 & 183970 & 1752 & 45 & 23 & 10 & 32 & 2.40 \\
\hline P45 & 469864 & 182667 & 2118 & 46 & 24 & 8 & 31 & 2.50 \\
\hline P46 & 462673 & 179683 & 2079 & 44 & 23 & 18 & 33 & 2.56 \\
\hline P47 & 454659 & 176501 & 2154 & 42 & 24 & 9 & 34 & 2.63 \\
\hline P48 & 448580 & 174642 & 2362 & 51 & 19 & 10 & 30 & 2.50 \\
\hline P49 & 438156 & 185927 & 1434 & 44 & 24 & 12 & 31 & 2.45 \\
\hline P50 & 396756 & 167243 & 1222 & 45 & 21 & 13 & 34 & 2.40 \\
\hline P51 & 389967 & 157998 & 1367 & 49 & 17 & 11 & 33 & 2.57 \\
\hline P52 & 394236 & 150337 & 1765 & 45 & 22 & 12 & 34 & 2.70 \\
\hline P53 & 410169 & 131201 & 2223 & 54 & 18 & 10 & 28 & 2.50 \\
\hline P54 & 430213 & 137871 & 2025 & 45 & 24 & 15 & 30 & 2.45 \\
\hline
\end{tabular}

\section{$\underline{\text { Soil Conservation Factor P }}$}

The erosion control practice factor is defined as the ratio of soil loss with a given surface condition to soil loss with up-and-down-hill plowing. It varies 
between 1 in a soil without erosion control practice and 0.1 when on a slight slope, we practice tied ridging (Erdogan et al., 2007).

\section{Sdr Module}

The sediment delivery ratio is concerned by the many physical characteristics of a watershed. It changes with the drainage area, slope, relieflength ratio, runoff-rainfall factors, land use/land cover and sediment particle size, etc. The empirical equations based on one or more factors are still useful tools to estimate the SDR (Zhou and Wu, 2009).

We used the slope of the main stream channel to predict the sediment delivery ratio (Muhammad Mukhlisin and Sukoco, 2011). The model is written as follow (see Equation 4):

$S D R=0.627 \times S L P^{0.403}$

Where the $S L P$ is the slope of drainage line in degree. In the first step, the drainage line was generated from the DEM using Arc Hydro Tools. Afterward the SDR for each cell in the flow path was computed in Arcgis using map algebra extension using the Eq.4 (Hui et al., 2010).

Each cell in the drainage line path can be viewed as the outlet of its upstream catchment. Therefore, at each cell the product of the SDR value and the annual soil loss amount upstream from that cell give us the net soil annual loss at that cell (Hui et al., 2010) .

\section{Results}

\section{Topographic Factor LS}

The integration of Eq.1 in map algebra extension gave us the LS factor map where the value ranges from 0 to 510 (see Figure 5) 
Figure 5. Spatial Distribution of LS Factor

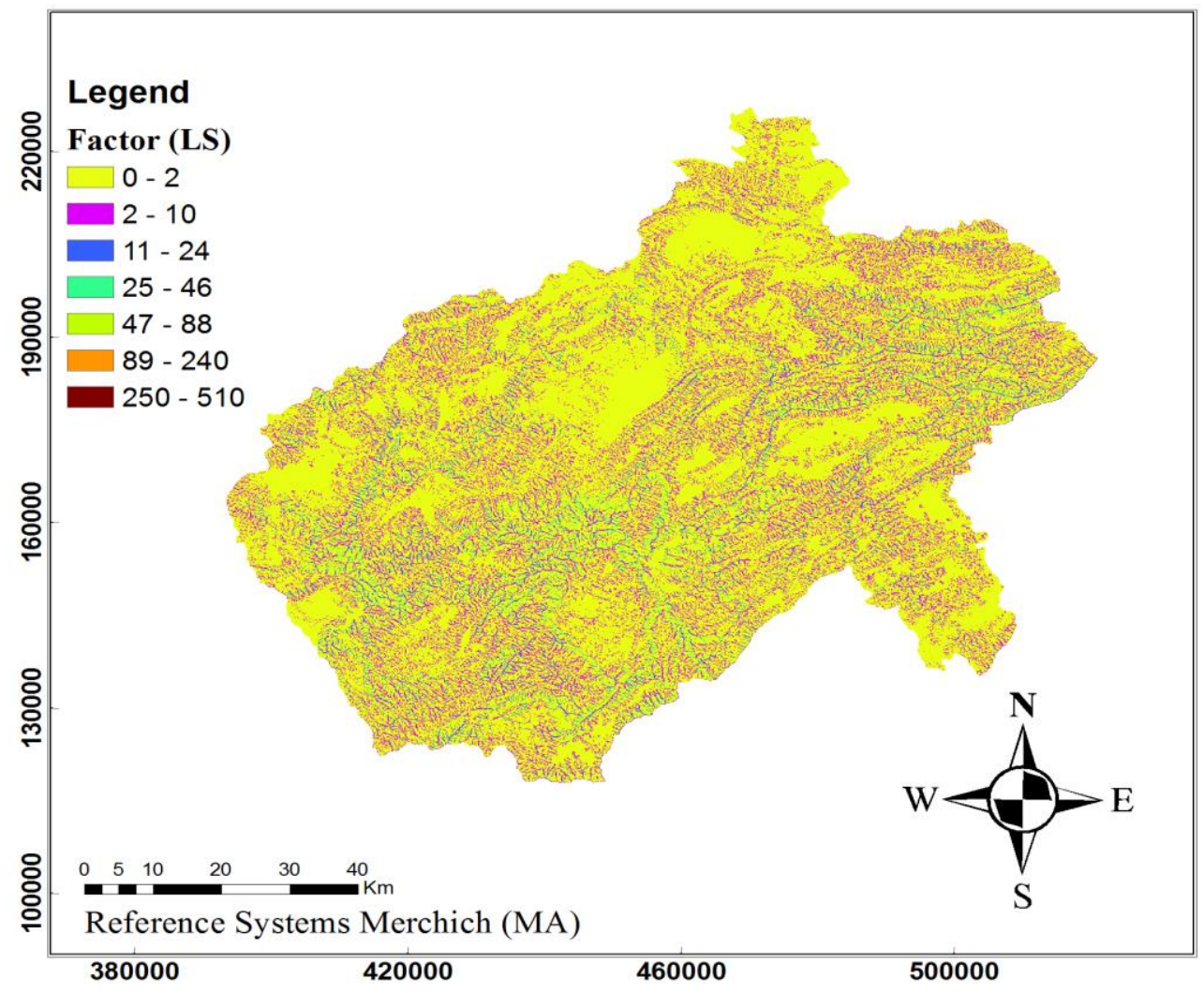

The distribution of the topographic factor shows that over $99.9 \%$ of the Oued El Abid watershed corresponds to a LS value below 46 (see Table 3).

Table 3. LS Factor Distribution

\begin{tabular}{|c|c|c|}
\hline LS Factor & Area (ha) & Percent \% \\
\hline $0-2$ & 661319.25 & 86.05 \\
\hline $2-10$ & 72338.05 & 9.41 \\
\hline $10-24$ & 29551.56 & 3.84 \\
\hline $24-46$ & 4377.95 & 0.57 \\
\hline $46-88$ & 809.02 & 0.10 \\
\hline $88-240$ & 126.92 & 0.01 \\
\hline $240-510$ & 3.17 & 0.0004 \\
\hline
\end{tabular}

Also large variations of LS values can be attributed to the complex mountainous terrain of the watershed, which is very typical in the areas affected by erosion.

\section{Rainfall Erosivity Factor $R$}

The results show that the factor value rises up from the East to West following the rain intensity (see Figure 6). 
Figure 6. Spatial Distribution of R Factor

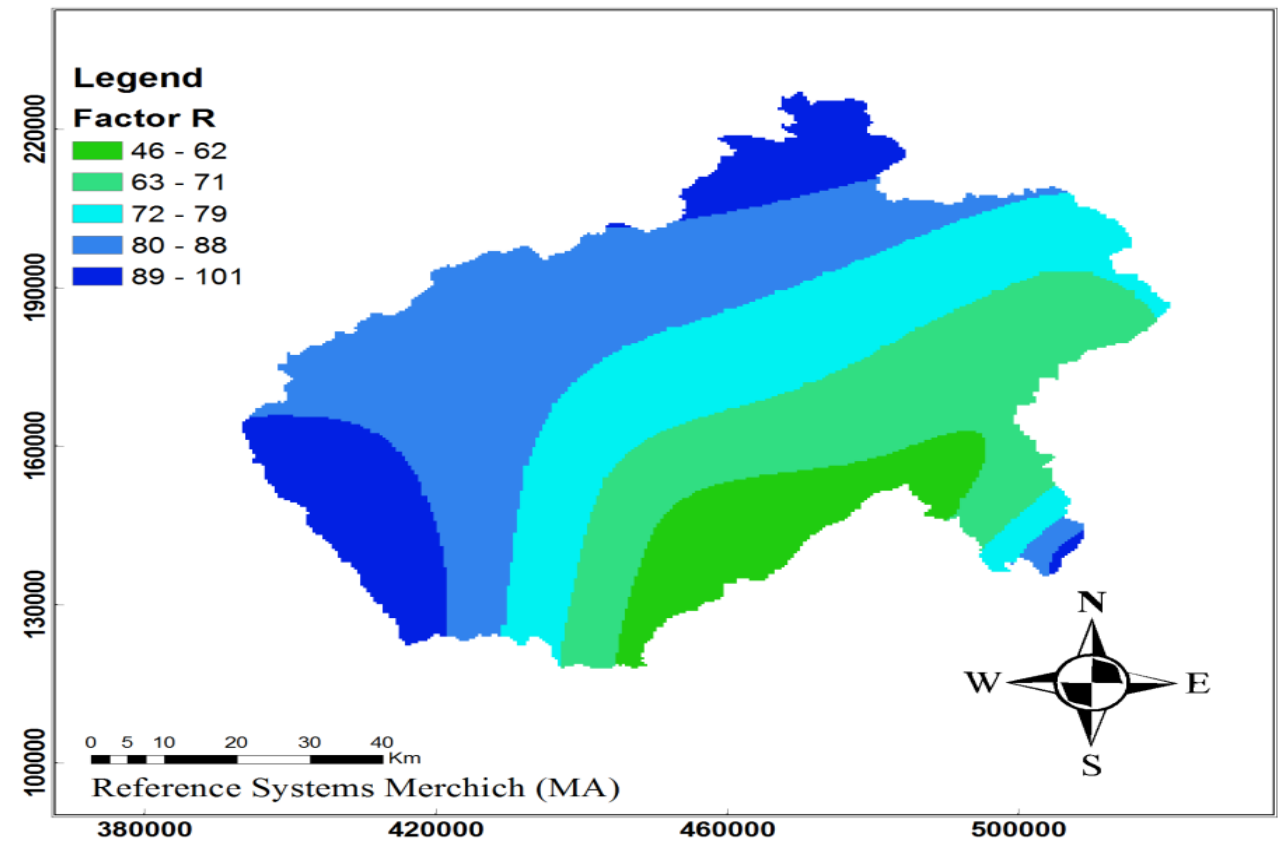

We see that the high value of precipitation coincides with areas covered, the thing which reduces the erosion affect.

\section{Soil Erodibility Factor $K$}

The values of the factor $\mathrm{K}$, located between 0.29 and 0.67 show a marked fragility of soils and their susceptibility to erosion (see Figure 7).

Figure 7. Spatial Distribution of K Factor

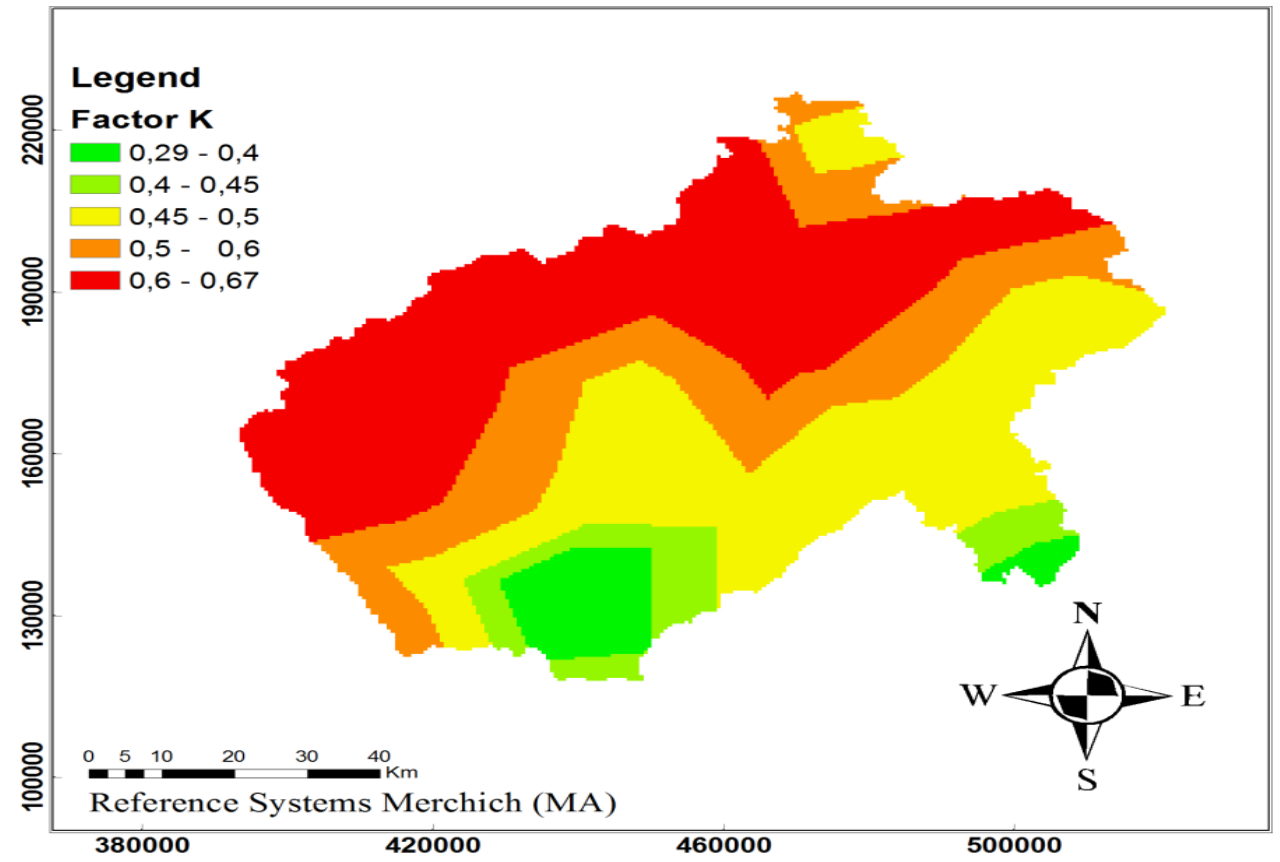


The bare soil has a lower erodibility value than covered soil but it is still a region which promotes the erosion phenomenon.

\section{Vegetation Cover Factor C}

The major lands used are the forest formations, rangelands, arboculture, water and bare soil (see Figure 8). View the kappa coefficient value which found equal to 0.96 the results of supervised classification are acceptable (Rawat, 2015) (see Table 4).

Table 4. Confusion Matrix: Truth Ground (Percent)

\begin{tabular}{|c|c|c|c|c|c|c|c|}
\hline & $\begin{array}{c}\text { Sparse } \\
\text { forest }\end{array}$ & Arboculture & $\begin{array}{c}\text { Range } \\
\text { land }\end{array}$ & $\begin{array}{c}\text { Bare } \\
\text { soil }\end{array}$ & Water & $\begin{array}{c}\text { Moderately } \\
\text { dense forest }\end{array}$ & $\mathbf{T}$ \\
\hline Sparse forest & 94.36 & 0 & 2.31 & 0.36 & 0 & 0 & 17.84 \\
\hline Arboculture & 0 & 100 & 0 & 0 & 0 & 0 & 0.24 \\
\hline Range land & 2.26 & 0 & 95.18 & 0 & 0 & 0 & 9.23 \\
\hline Bare soil & 3.38 & 0 & 2.51 & 99.64 & 0 & 0 & 67.18 \\
\hline Water & 0 & 0 & 0 & 0 & 100 & 0 & 3.35 \\
\hline $\begin{array}{c}\text { Moderately } \\
\text { dense forest }\end{array}$ & 0 & 0 & 0 & 0 & 0 & 100 & 2.15 \\
\hline T & 100 & 100 & 100 & 100 & 100 & 100 & 100 \\
\hline
\end{tabular}

Figure 8. The Occupation of Land Use Map

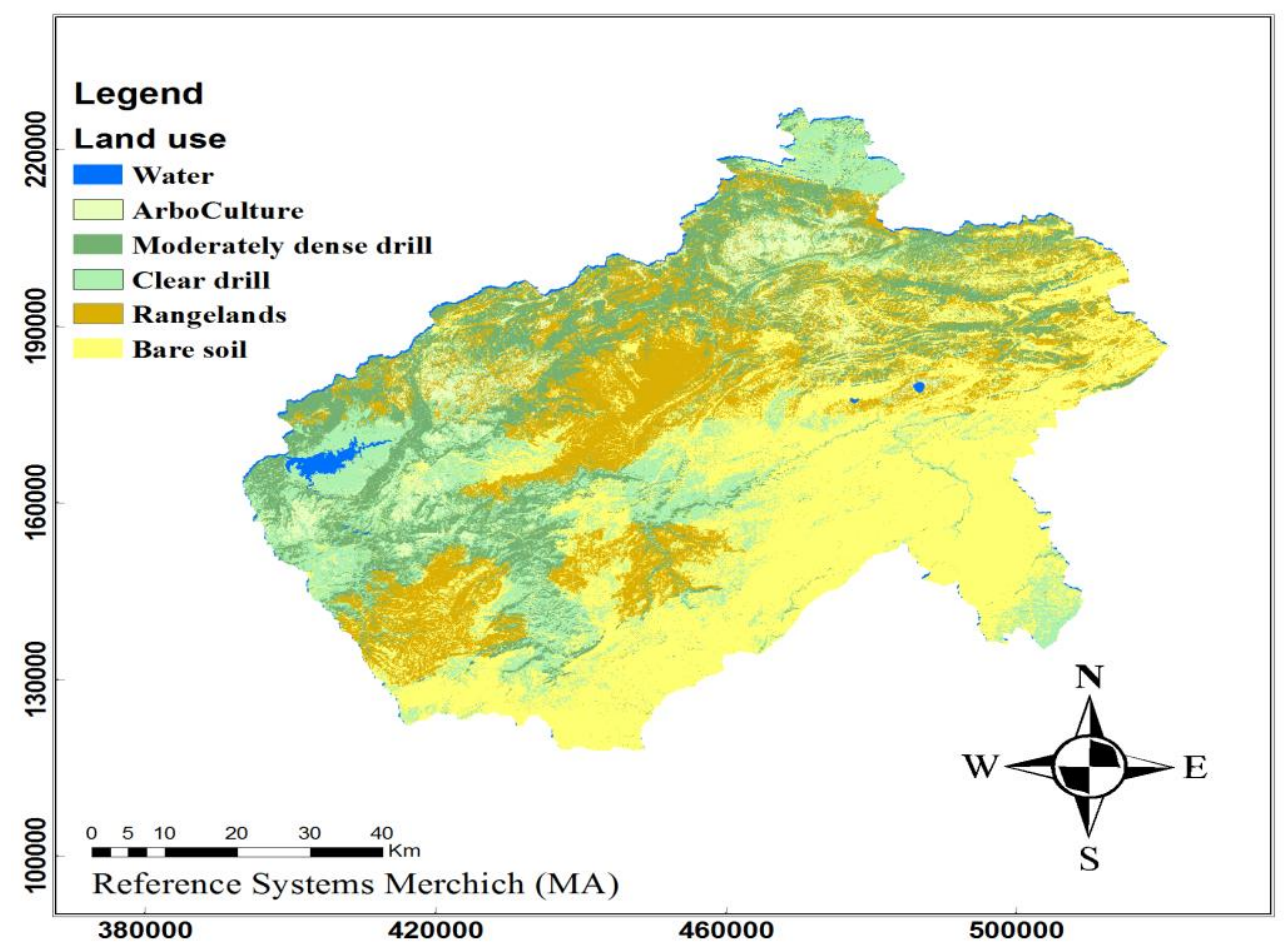

The results show that the $\mathrm{C}$ factor value range from 0 in water plan to 0.8 in bare soil (see Figure 9). 
Figure 9. Spatial Distribution of C Factor

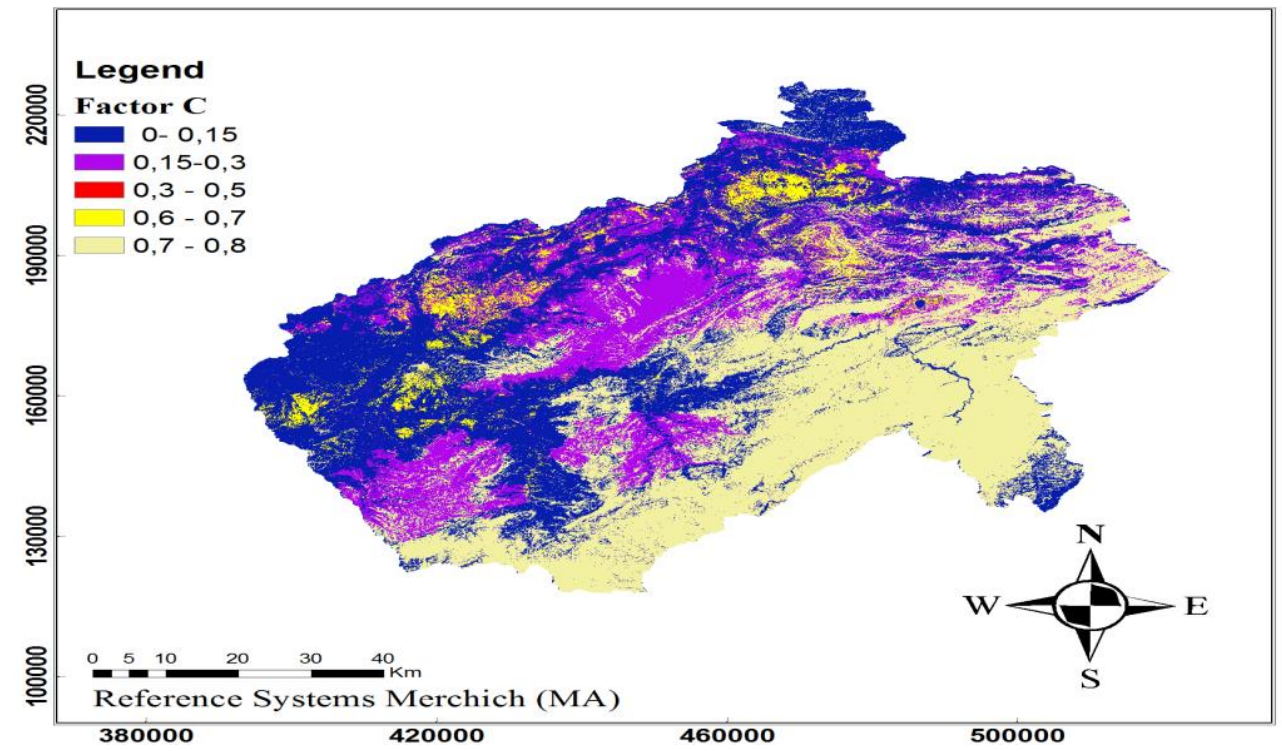

\section{Soil Conservation Factor P}

The inspection of the property shows the absence of erosion control practice, thus a value of "1" is attributed to this factor.

\section{Soil Loss}

After we combine all these five factors we got the soil loss in $t / h a / y e a r$ (see Figure 10).

Figure 10. Spatial Distribution of Soil Loss

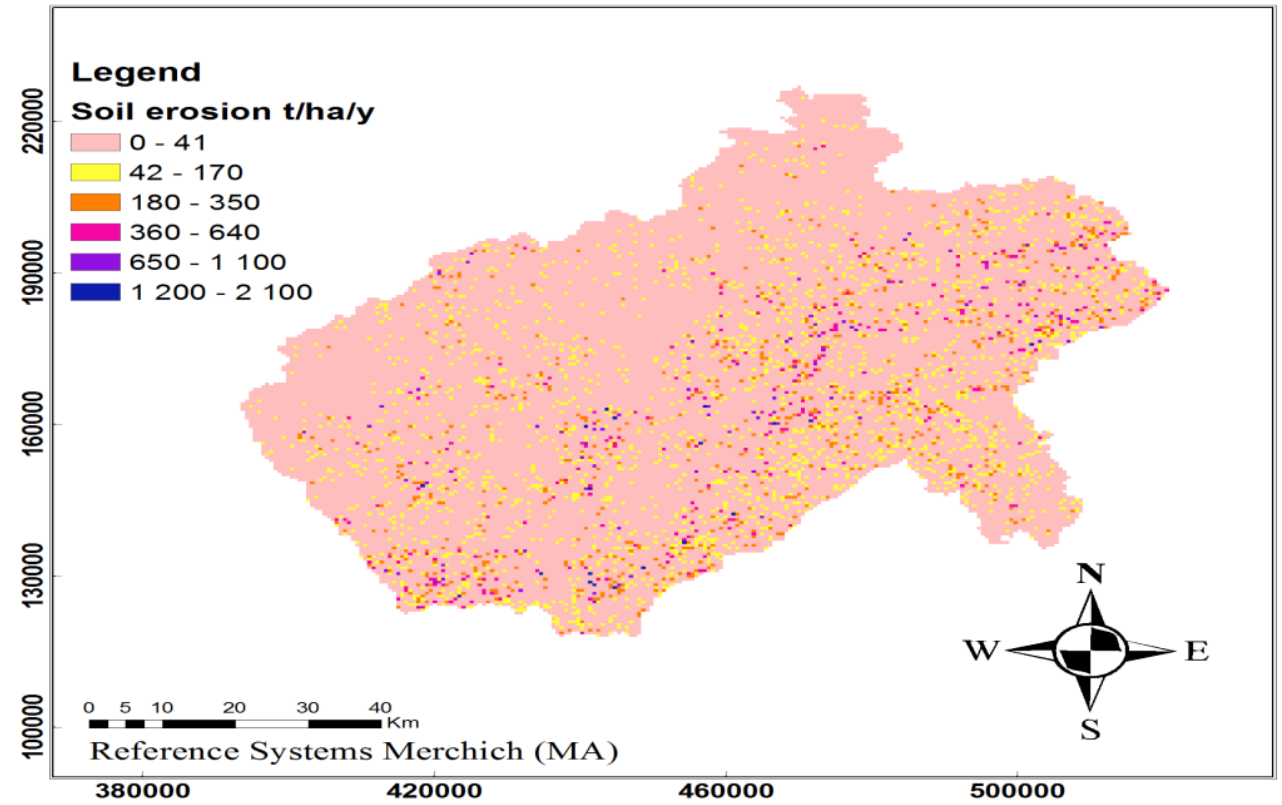


The results show that the commune called Agoudim is the most degraded with $77.66 \mathrm{t} / \mathrm{ha} / \mathrm{y}$ (see Table 5).

Table 5. Soil Loss in Each Commune

\begin{tabular}{|l|c|c|c|c|}
\hline \multicolumn{1}{|c|}{ Commune } & $\begin{array}{c}\text { Area } \\
\text { (ha) }\end{array}$ & $\begin{array}{c}\text { Min } \\
(\mathrm{t} / \mathrm{ha} / \mathrm{y})\end{array}$ & $\begin{array}{c}\text { Max } \\
(\mathrm{t} / \mathrm{ha} / \mathrm{y})\end{array}$ & Mean (t/ha/y) \\
\hline Aghbala & 44895.74 & 0 & 977,55 & 18,59 \\
Tizi N'isly & 34590.77 & 0 & 515.62 & 7.38 \\
Timoulilt & 1633.71 & 0 & 101.88 & 2.39 \\
Naour & 2576.24 & 0 & 161.47 & 6.88 \\
Ait Ouaqbili & 10524.89 & 0 & 195.00 & 4.71 \\
Tounfit & 6723.37 & 0 & 405.93 & 34.88 \\
Tanougha & 2293.48 & 0 & 275.38 & 7.72 \\
S.Y.Oyoussef & 24411.47 & 0 & 1069.95 & 17.82 \\
Ouaouizeght & 20201.51 & 0 & 977.07 & 13.53 \\
Tabaroucht & 13666.65 & 0 & 814.63 & 20.52 \\
T. N. Hamza & 19667.41 & 0 & 548.89 & 6.93 \\
Anemzi & 31951.69 & 0 & 1065.81 & 43.32 \\
B.El Ouidane & 8545.59 & 0 & 149.58 & 2.46 \\
Ait Yahia & 10713.40 & 0 & 1067.44 & 64.89 \\
Isseksi & 6346.35 & 0 & 206.92 & 9.84 \\
Tagleft & 38455.14 & 0 & 573.29 & 12.78 \\
Outerbat & 1759.39 & 0 & 1144.26 & 53.73 \\
Boutferda & 73045.91 & 0 & 1032.11 & 24.56 \\
Anergui & 22872.01 & 0 & 1306.91 & 24.00 \\
A.N'lkhair & 14703.43 & 0 & 669.56 & 12.71 \\
Tilougguite & 46843.63 & 0 & 1196.28 & 24.88 \\
Ait Mazigh & 18567.80 & 0 & 1028.00 & 16.59 \\
Imilchil & 55923.32 & 0 & 2100.00 & 37.92 \\
Bou Azmou & 67453.58 & 0 & 802.15 & 31.81 \\
Ayt mhamed & 13383.90 & 0 & 889.08 & 19.88 \\
Agoudim & 6566.28 & 0 & 1338.53 & 77.66 \\
Zaouit Ahnsal & 98745.50 & 0 & 1611.09 & 26.28 \\
\hline
\end{tabular}

Sdr and Net Soil Loss

The SDR value at the outlet of Oued El Abid watershed is estimated at 0.65 (see Figure 11) then the sediment yield was found to be 12.74 million t/a. 
Figure 11. Sediment Delivery Ratio

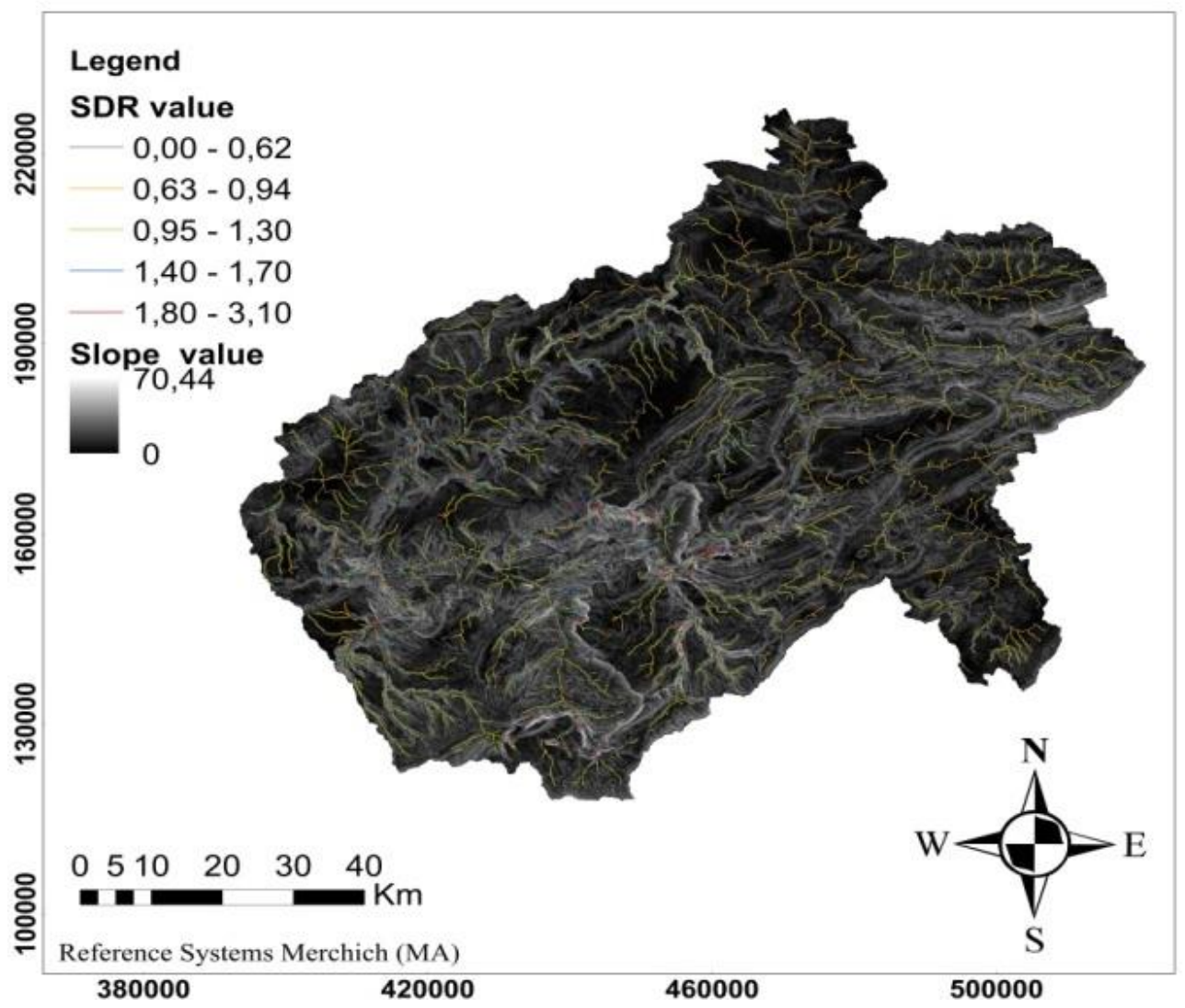

The analysis of soil samples showed a mean soil density of $2.45 \mathrm{t} / \mathrm{m}^{3}$ (see table 5), thus the sediment yield is estimated at $5.2 \mathrm{Mm}^{3} /$ year.

\section{Discussion}

The results presented suggest that taking the sediment delivery ratio into account greatly reduces the total sediment output compared to what is calculated from the USLE.

In the North-Morocco many studies performed by (Rahhou, 1999; Al Karkouri, 2003; Aroussi et al., 2011) had focused on erosion phenomenon, but they had not addressed the sedimentation delivery phenomenon. (El Garouani et al. 2008) have used a sedimentation model based on the revised universal sol loss equation and the spatial variability of the field to estimate the amount of soil load for the Tlala watershed outlet. Recently (El Gaatib and Erraji, 2014) did a study in the Oued el Beht watershed based on the USLE model.They coupled the rainfall and flow rate in order to estimate the transport of sediment to the El Kansra dam.

(Lahlou, 1982) used practical methods (bathymetry, topography survey , turbidimetry measurement, emptying an filing of dam) in order to estimate the silting rate in 27 dams across Morocco, the annual silting rate was estimated to 
be between 1,35 and 10 million $\mathrm{m}^{3}$. As regard the Bin El Ouidane dam the author used the curve extrapolation of specific degradation of watershed surface based on measurements from watersheds. The annual silting rate was estimated to be 1,5 millions $\mathrm{m}^{3}$.

The bathymetric measurement between the years 1953 and 2008 showed a sediment yield rate of 5 million $\mathrm{m}^{3} /$ year (see table 6 ).

Table 6. Bathymetric Results

\begin{tabular}{|c|c|c|c|c|}
\hline Year & $\begin{array}{c}\text { Volume } \\
\left(\mathbf{M m}^{3}\right)\end{array}$ & $\begin{array}{c}\text { Sediment yield } \\
\left(\mathrm{Mm}^{3}\right)\end{array}$ & $\begin{array}{c}\text { Annual lose } \\
\left(\mathbf{M m}^{3} / \mathbf{Y}\right)\end{array}$ & $\begin{array}{c}\text { Sediment } \\
\text { yield rate } \\
\left(\mathbf{M m}^{3} \mathbf{Y}\right)\end{array}$ \\
\hline 1953 & 1507.5 & & 4.9 \\
\hline 1991 & 1320.6 & 186.9 & 5.9 \\
\hline 1994 & 1302.8 & 17.8 & 18.6 \\
\hline 1996 & 1265.5 & 37.2 & $\mathbf{5}$ \\
\hline 2000 & 1254.6 & 10.9 & 2.7 \\
\hline 2003 & 1242.7 & 11.9 & 4.0 \\
\hline 2008 & 1233.1 & 9.6 & 1.9 \\
\hline
\end{tabular}

The differences between the result obtained by the dual focus on erosion and deposition and this given by the specific degradation (Lahlou, 1982) are due to the global warm which was expected to conduct to a moderate hydrological cycle, with high rainfall totals.

The new proposed method in Morocco gives results are acceptable compared to those given by validation methods that are more accurate and expensive with a slight overestimation does not exceed $0.04 \%$ maximum. This method is also applicable on all watersheds regardless the superficies, then it can be considered technically a reliable method and deserves to be applied instead of the commonly used.

The Erosion values obtained by the application of this method may vary significantly due to different weather conditions. By against the long term, the mean values obtained by USLE and its rectified version RUSLE represent the soil losses more accurately (Stone and Hilborn, 2012).

Indeed, the confidence for the factors values cannot be defined by lack of validation on the parcels for calibration. Custom field will be the subject of our next step in our project. 


\section{Conclusions}

Taking into account the variability of erosion and deposition processes at the same time resulted in reducing the estimated soil erosion values calculated by the USLE model. Although the results obtained by this study are questionable because of probability of error in the data used and the limits of the USLE model when applied to the large watershed, this method provides an important support to decision makers and planners to simulate scenarios for the evolution of the region and plan interventions against erosion. It also helps to monitor the impact of land use and development on the quality of soil resources.

\section{References}

ABHOER - Agence du bassin Hydraulique d'Om Er Rabia (2015) Fiche annuelle de l'evolution de la capacité des barrages (Région Beni Mellal-Khenefra) [Annual report on the evolution of dam capacity (Beni Mellal-Khenefra Region)].

Al Karkouri J. (2003) Dégradation du milieu naturel dans le bassin de Beni Boufrah (Rif Central - Maroc) : analyse des facteurs [Degradation of the natural environment in the Beni Boufrah basin (Rif Central - Morocco): analysis of the factors]. Mohammed V.

Alexakis D. D., Hadjimitsis D. G., Agapiou A. (2013) Integrated use of remote sensing, GIS and precipitation data for the assessment of soil erosion rate in the catchment area of "Yialias" in Cyprus. Atmospheric Research 131:108-124. doi: 10.1016/j.atmosres.2013.02.013.

Aroussi O. El, Mesrar L., Garouani A. El, Lahrach A., Beaabidate L., Akdim B. (2011) Predicting the Potential Annual Soil Loss Using the Revised Universal Soil Loss Equation ( Rusle ) in the Oued El Malleh Catchment (Prerif, Morocco). Present Environment and Sustainable Development 5:5-16.

Burns P., Nolin A. (2014) Remote Sensing of Environment Using atmosphericallycorrected Landsat imagery to measure glacier area change in the Cordillera Blanca, Peru from 1987 to 2010. Remote Sensing of Environment 140:165-178. doi: 10.1016/j.rse.2013.08.026.

Dewitte O., Jones A., Spaargaren O., Breuning-Madsen H., Brossard M., Dampha A., Deckers J., Gallali T., Hallett S., Jones R., Kilasara M., Le Roux P., Michéli E., Montanarella L., Thiombiano L., Van Ranst E., Yemefack M., Zougmore R. (2013) Harmonisation of the soil map of africa at the continental scale. Geoderma 211212:138-153. doi: 10.1016/j.geoderma.2013.07.007.

El Gaatib R., Erraji A. LA (2014) Impact des processus d'erosifs sur les resources naturelles des bassin hydrographiques et sur l'état d'envasement des retenues des barrages: Application au bassin versant de Oued Beht en amont du barrage El Kansra Maroc [Impact of erosive processes on the natural resources of river basins and the silting condition of dam reservoirs: Application to the Oued Beht watershed upstream of the El Kansra dam Morocco]. Geo Observateur 21:35-45.

El Garouani A., Chen H., Lewis L., Tribak A., Abharour M. (2008) Cartographie De L'Utilisation Du Sol Et De L'Érosion Nette À Partir D'Images Sa ${ }^{\mathrm{TEL}}$ Litaires Et Du Sig Idrisi Au Nord-Est Du Maroc [Mapping of Land Use and Net Erosion from Saigon Images and Idrisi Sig in Northeastern Morocco]. Télédétection 8:193-201. 
Erdogan E. H., Erpul G., Bayramin İ. (2007) Use of USLE/GIS Methodology for Predicting Soil Loss in a Semiarid Agricultural Watershed. 153-161. doi:10. 1007/s10661-006-9464-6.

Flanagan D. C., Gilley J. E., Franti T. G. (2007) Water Erosion Prediction Project (WEPP): Development History, Model Capabilities and Future Enhancements. Asabe 50:1603-1612.

Hui L., Xiaoling C., Lim K. J., Xiaobin C., Sagong M. (2010) Assessment of soil erosion and sediment yield in Liao watershed, Jiangxi Province, China, Using USLE, GIS, and RS. Journal of Earth Science 21:941-953. doi: 10.1007/s12583$010-0147-4$

Lahlou A. (1982) La degradation specifique des bassins versants et son impact sur l' envasement des barrages [The specific degradation of watersheds and its impact on silting of dams]. Recent Developments in the Explanation and Prediction of Erosion and Sediment Yield (Proceedings of the Exeter Symposium, July 1982). IAHS 137:163-169.

Morgan R. P. C., Quinton J. N., Smith R. E., Govers G., Poesen J. W. A., Chisci G., Torri D. (1998) The EUROSEM model. Modelling soil erosion by water Proceedings of the NATO Advanced Research Workshop "Global change: modelling soil erosion by water", University of Oxford, Oxford, UK, 11-14 September, 1995 389-398.

Namr K. I., Mrabet R. (2004) Influence of agricultural management on chemical quality of a clay soil of semi-arid Morocco. Journal of African Earth Sciences 39:485-489. doi: DOI 10.1016/j.jafrearsci.2004.07.016.

Panagos P., Meusburger K., Ballabio C., Borrelli P., Alewell C. (2014) Science of the Total Environment Soil erodibility in Europe: A high-resolution dataset based on LUCAS. Science of the Total Environment, The 479-480:189-200. doi: 10.1016/j.scitotenv.2014.02.010

Rahhou M. (1999) L'érosion dans le Prérif central, zone interfluviale Leben-SebouOuergha, un prolongement de l'évolution naturelle, une production sociale [Erosion in the central Prerif, the Leben-Sebou-Ouergha interluvial zone, an extension of natural evolution, a social production]. Mohammed V.

Rawat J. S. (2015) Monitoring land use / cover change using remote sensing and GIS techniques: A case study of Hawalbagh block, district Almora, Uttarakhand, India. The Egyptian Journal of Remote Sensing and Space Sciences 18:77-84. doi: 10.1016/j.ejrs.2015.02.002.

Renard K., Foster G., Weesies G., McCool D., Yoder D. (1997) Predicting soil erosion by water: a guide to conservation planning with the Revised Universal Soil Loss Equation (RUSLE). Agricultural Handbook No. 703404.

Muhammad Mukhlisin and Sukoco (2011) Utilizing Geographic Information System for Prediction of Soil Erosion in Sono Sragen Catchment Area. American J. of Engineering and Applied Sciences 4 (2): 270-275.

Stone R. P., Hilborn D. (2012) Universal Soil Loss Equation (USLE). 1-8.

Suhua F., Zhiping W., Baoyuan L., Longxi C. (2013) Comparison of the Effects of the Different Methods for Computing the Slope Length Factor at a Watershed Scale. International soil and water conservation research 1:64-71. doi: 10.1016/S20956339(15)30040-X.

Van Remortel R. D. D, Maichle R. W. W., Hickey R. J. J. (2004) Computing the LS factor for the Revised Universal Soil Loss Equation through array-based slope processing of digital elevation data using a $\mathrm{C}++$ executable. Computers \& Geosciences 30:1043-1053. doi: 10.1016/j.cageo.2004.08.001.

Wang G., Hapuarachchi P., Ishidaira H., Kiem A. S., Takeuchi K. (2009) Estimation of 
Soil Erosion and Sediment Yield During Individual Rainstorms at Catchment Scale. Water Resources Management 23:1447-1465. doi: 10.1007/s11269-008-9335-8.

Wischmeier W. H., Smith D. D. (1978) Predicting Rainfall Erosion Losses. Agriculture Handbook No 53769.

Zhang J., Li Q., Gong H., Li X. (2010) Hydrologic Information Extraction Based on Arc Hydro Tool and DEM. 504-507. doi: 10.1109/CESCE.2010.169.

Zhou W., Wu B. (2009) Assessment of soil erosion and sediment delivery ratio using remote sensing and GIS : a case study of upstream Chaobaihe River catchment, north China. 23:167-173.

Zhu A., Wang P., Zhu T., Chen L., Cai Q., Liu H. (2013) Modeling runoff and soil erosion in the Three - Gorge Reservoir drainage area of China using limited plot data. Journal of Hydrology 492:163-175. doi: 10.1016/j.jhydrol.2013.03.038. 